\title{
The Relevance of Information Systems Research: Informing the IS Practitioner Community; Informing Ourselves
}

\author{
Theresa A. Steinbach and Linda V. Knight \\ DePaul University, Chicago, IL, USA
}

\author{
tsteinbach@cti.depaul.edu Iknight@cti.depaul.edu
}

\begin{abstract}
Discussion of the relevance of Information Systems research to the practitioner community began in the 1990s. Though the issue has faded from top-tier journals, the problem remains. This article provides the first comprehensive consideration of the major papers relating to IS research relevance. It also recognizes that the problem of relevance is not one that is likely to be solved at the global IS level, or even the university level. Rather, the relevance of IS research ultimately will be determined by each individual researcher. To facilitate individual researchers' progress in moving toward greater relevance, this research provides a concise plan of specific actions that are within the control of each individual IS researcher. These actions involve both how researchers attempt to inform the practitioner community about their work, and how researchers inform themselves about the concerns of practitioners. Several specific actions for improving the relevance of individual research are detailed.
\end{abstract}

Keywords: rigor, relevance, research, practitioner, academic, journal, research agenda, information systems

\section{Introduction}

The discipline of information systems (IS) is relatively young when compared to other bodies of inquiry. The institutionalized use of computers in the 1960s for transaction processing and reporting ("Information Systems," 2003), and the infusion of technology for enhancing productivity and competitive advantage in the 1970s (Bhattacherjee, 2001) created the need for an IS academic community. Academic research requires rigor; the applied nature of IS research requires relevance. Robey and Markus (1998) write, “... the symbols of rigor: copious references, formal notation, detailed statistical analyses and theoretical abstractions...the symbols of relevance: simple graphs, 2x2 typologies, "bulleted” summaries, and punchy anecdotes." can be contradictory pressures for IS researchers. Lack of relevance in IS research was first noted by Peter Keen at the 1990 IFIP conference at Copenhagen (as cited in Bhattacherjee, 2001). The issue was popularized

Material published as part of this publication, either on-line or in print, is copyrighted by the Informing Science Institute. Permission to make digital or paper copy of part or all of these works for personal or classroom use is granted without fee provided that the copies are not made or distributed for profit or commercial advantage AND that copies 1 ) bear this notice in full and 2) give the full citation on the first page. It is permissible to abstract these works so long as credit is given. To copy in all other cases or to republish or to post on a server or to redistribute to lists requires specific permission and payment of a fee. Contact Publisher@InformingScience.org to request redistribution permission. again in the late 1990s when the Winter 1998 issue of Information Resources Management Journal published two articles and MIS Quarterly devoted a significant portion of the March 1999 issue to the topic. A special volume on relevance was printed by the Communications of the Association for Information Systems in 2001. It was predicted by Paul Gray (2001) that this would not be 
the last discussion on the issue. He was correct. Informing Science published a special series titled Informing Each Other in 2003 focusing on the gap between research and practice (Fitzgerald, 2003).

\section{Considering the Relevance of IS Research}

\section{Beginning the Discussion (1998)}

Robey and Markus (1998) first detailed the problems IS researchers face while attempting to serve two masters: standards of the academy and the practitioner audience. The standards of the academy are the benchmarks for which tenure and promotion dossiers are evaluated. The highlyvalued qualities of an extensive literature review, references to peer-reviewed journal articles, sophisticated statistical analyses and model-building are of little value to the practitioner if practical and timely advice are not included and communicated in an appealing style of writing. The constant and rapid changes in technology accelerate the need to produce practical research on emerging technologies. Robey and Markus outline four strategies to satisfy both consumers of information. The first two strategies outline support and methodology; the last two address communication methods. The first strategy is to cultivate practitioner sponsorship for IS research by academics. This funding ensures that the practitioner's research needs are met by scientificallytrained investigators. The Advanced Practices Council (APC) of the Society for Information Management (SIM) offers funding for projects that APC members identify as their highest priority for leveraging IT for competitive advantage.

(http://www.simnet.org/Content/NavigationMenu/Advanced_Practices_Council/Overview10/Ove rview.htm). University research centers that are supported by private contributions can focus on specific interests of that organization or agency. The second strategy is to adopt new research models. Traditional IS research methodology follows the social sciences practices however research models used by policy studies and education are appropriate for IS research. Applied theory, evaluation research and policy research simultaneously support both rigor and relevance. The ability to communicate results of the research should appeal to both audiences. The third strategy is producing consumable research reports that have four key characteristics: an appealing style that is clear and simple; a story line that connects the reader to the problem and provides a solution; an evidential base that is described and explained in a simple but credible manner; and support from useful and usable logic and theory that focus on things that can be controlled. The fourth strategy is academic support for nontraditional research outlets. “...we value these sources ... more than we value our own papers in leading academic journals.” (Robey \& Markus, 1998, p. 8).

Senn (1998), writing in the same issue of Information Resources Management Journal, independently reports that the research conducted by IS scholars is not valued by a large number of the practitioner community. While he echoes the previously stated strategies of forming alliances with practitioners and focusing on communicating the research findings through multiple versions of research reports dependent on the audience, Senn also suggests researchers focus on important practitioner issues. He cites SIM's APC and the annual report, Critical Issues of Information Systems Management, produced by Computer Science Corporation (last published in 2001) as primary sources of CIO management and critical technology issues. Research that confirms prior assumptions and beliefs has limited, if any value to the practitioner. IS academic researchers must select methods of research that generate theories, ideas and hypothesis that produce objective findings. Lastly, Senn recommends establishing a personal or institutional research program focusing on a general area of investigation. Using multiple methods that examine those previously identified important issues can identify the underlying theory or the probable impact if no theory is identified. 


\section{The Discussion Continues (1999-2001)}

The March 1999 issue of MIS Quarterly included an opinion piece on rigor and relevance in MIS research with commentary by other noted IS researchers. Benbasat and Zmud (1999) begin their investigation with a definition of relevance. The most "relevant" topic to practitioners is that which is implementable and pragmatic. An article's relevance lies in the ability to exploit an opportunity or resolve a problem. According to Benbasat and Zmud, rigor is no longer an issue for academic IS research. In the effort to compete with other business school disciplines, the quality of IS research is comparable to those disciplines, and cumulative traditions are beginning to develop in a number of theoretical streams that comprise the IS discipline. Eight recommendations are given for increasing the relevance of IS academic research. The first three recommendations concern research topic. Similar to Senn, topics should be chosen with careful attention to areas of interest to senior practitioners. In addition to "key issues" surveys, these topics can be culled through academic/practitioner discussions of key research areas, academics attending practitioner conferences and developing personal relationships with individual practitioners. Due to the publication cycle for academic journals, Benbasat and Zmud recommend focusing on fundamental issues that are likely to be important in three years. The next four recommendations are directed toward an article's purpose. IS researchers should focus on likely outcomes of the research that might be utilized by practitioners; produce cumulative, theory-based, context-rich bodies of research that provide usability; and develop frames of reference that practitioners can grasp and apply to their organization. The last two recommendations are similar to Robey and Markus' communication strategies. An article should be written in a clear, simple and concise manner that provides accessibility for all potential readers. Editorial review boards of the leading IS journals are encouraged to publish articles that are characterized by both rigor and relevance. Davenport and Markus (1999) refute four recommendations of Benbasat and Zmud. Since the IS discipline has an applied nature, better role models to emulate are those with clinical practices, e.g. medical and law. Practitioner publications should be valued by the IS academic community and IS journals should be more practitioner accessible. IS academic researchers should integrate consultants' key success factor, rapid production of research, with academic rigor. Senior practitioners are not the only valued consumer of IS research; undergraduate students are prospective practitioners and graduate students are current practitioners and at some point will be the senior practitioners. Lee (1999) concurs with Davenport and Markus and strengthens their statement that IS research should emulate research in medicine and law by noting that medicine and law are not natural sciences, but professions. The goal of research in the professions is effectiveness in actions. He recommends that IS research should be conducted in the inquiry methods of both the natural sciences (theory-driven) and the manner of the professions (practice-driven).

Watson, Taylor, Higgins, Kadlec and Meeks (1999) interviewed 17 leaders in the IS academic field in October - November 1998, prior to the MIS Quarterly publication discussed above. All agreed that IS research had become more rigorous. However, the appropriate balance between rigor and relevance of IS research was addressed without consensus. Primary audience (academics vs. practitioners), research issues (temporal vs. longer-lasting value), and journals (academic vs. trade) had proponents on either side.

Westfall (1999) concludes that IS has a window of opportunity to proactively take action in the issue of relevance as it relates to research topics, journal policies and procedures, and institutional (tenure and promotion) considerations. Three stakeholders are defined: relevance to students, relevance to practitioners, and stature within the academic community. Research topics contrary to commercial interests, unsolved problems, and issues economically unattractive to commercial researchers are three scenarios that provide a positive impact on the defined stakeholders. Journals need to speed up cycle times, increase electronic access to their content, involve practitioners in reviews and revise norms for style and tone positively impact all stakeholders. 
The Communications of the Association for Information Systems (CAIS) devoted a special volume to the issue of relevance in March 2001. It is interesting to note that there was no mention of rigor in this special issue volume. There was consensus that practitioners do not read published work in leading IS journals. Reasons included the previously stated abstractness of the research and the quality of writing. Also included was the observation that there is a lack of practical experience of faculty (Gray, 2001). Unique to this publication was the inclusion of a practitioner's position paper. Glass (2001) argued that IS research cannot be both rigorous and relevant. "Rigorous experimental research demands a highly controlled, limited-scope environment. But for research to be useful to the world of practice, it should be conducted in an environment as close to that real world as possible. And the real world is hardly highly controlled and of limited scope.” Most articles written by academic researchers in this special issue agree that this dichotomy exists and that it should continue to exist. Dennis (2001) acknowledged two distinct constituencies that must be served by IS research with very dissimilar expectations: knowledge exploration for academics and knowledge exploitation for practitioners. Knowledge exploration is to change the future, not assist the present and knowledge exploitation should be left to the professional schools, i.e. computer science and engineering. Bhattacherjee (2001) focused his evaluation of relevance on the needs and concerns of the stakeholder. Using the expectations of business professionals to evaluate relevance in basic (academic) research which may not deliver any tangible business value for several years or decades would be problematic just as academics would have difficultly in accurately judging the relevance of practitioner-oriented projects. SIM's APC is an attempt to bridge the expectations. Khazanchi and Munkvold (2001) expanded on the definition of stakeholder to include practitioners, scholars, educators, users, politicians, economists, citizens, society, nation and global. The potential value of the research and the character of relevance can vary considerably within each of these groups. The transient nature of the time frame for relevance was discussed and how the rapid change and advancement in technology may compress that time frame.

\section{And the Discussion Continues (2003)}

The special series "Informing Each Other" issued by Informing Science is introduced by Fitzgerald (2003) with the premise "... that practice has often preceded theory in the IS field." The Sage missile-defense system and the SABRE airline reservation system are cited as examples of sophisticated systems that exceeded the maturity of the theory at the time. Also stated is his belief that more research is needed in real context. Söderström and Nordström (2003) propose the development of a "regional IS knowledge network" to make researchers more aware of practice and practitioners more aware of IS academic research. They suggest a research and development cooperative effort between academics and companies within a specific geographic region. This consortium will focus on concrete projects that synthesize existing knowledge and experiences, disseminate information through seminars, workshops and conferences to both members and nonmembers of the consortium, and culminate in action. Moody (2003) and Lang (2003) focus on the failure of traditional dissemination channels and communication breakdown of IS research. Jordens et al. and Phillips (as cited in Moody, 2003) claim that "For research to make a practical difference, research results must be readily available to practitioners, and must be actively used and implemented in everyday practice.” Moody substantiates these claims through two case studies and the use of the World Wide Web to provide systematic reviews, on-line literature searching tools, posting or practitioner-developed "knowledge products", and using listservers. Lang argues that communication problems between academics and practitioners have three critical aspects. (1) A lack of a suitable communication channel. (2) The style and form of academic writing presents a language barrier. (3) Few academics have adequate real-world experience while practitioners are capable of devising solutions to IS problems independent of academic input. To solve these problems, Lang recommends actions to provide incentive for academics to consider IS practitio- 
ners as consumers of university-based research. Professional experience and competency in technical skills should be considered during the evaluation process as well as instructors who blend applied teaching methods with academic theory. Additional recommendations echo previous suggestions: more recognition should be given to publications in peer-reviewed books and practitioner-based outlets; researchers should consider electronically publishing their work in practitionerfriendly forms such as reports, briefs and white papers; a more fluid and open writing style should be used; and IS researchers should consider spending more time within industrial contexts.

\section{Actions for a Relevant IS Research Agenda}

As the prior discussion has shown, there have been dozens of suggestions for how we might improve the relevance of IS research to the practitioner community. When actual action items are sifted from the more general rhetoric, five major areas for potential action emerge. These five areas and the relationships among them are depicted in Figure 1. As this figure shows, a researcher might employ activities in Table 1 to improve the relevance of their research topics and Table 2 to improve the relevance of their methodology. They might then select actions in Table 3 to improve dissemination of their research results to the practitioner community. Further, the actions listed in Table 4 might be used to build closer relationships with, and a greater understanding of practitioners. Closer relationships between researcher and practitioner may also define better topics and methodology. Finally, the actions in Table 5 might be used by universities to encourage more relevant research through the faculty evaluation program. Clearly all of these actions would not be employed by any one group of researchers or any one university; however, taken as a whole, they provide the first attempt at comprehensively identifying those potential actions that could be taken to improve the relevance of IS research.

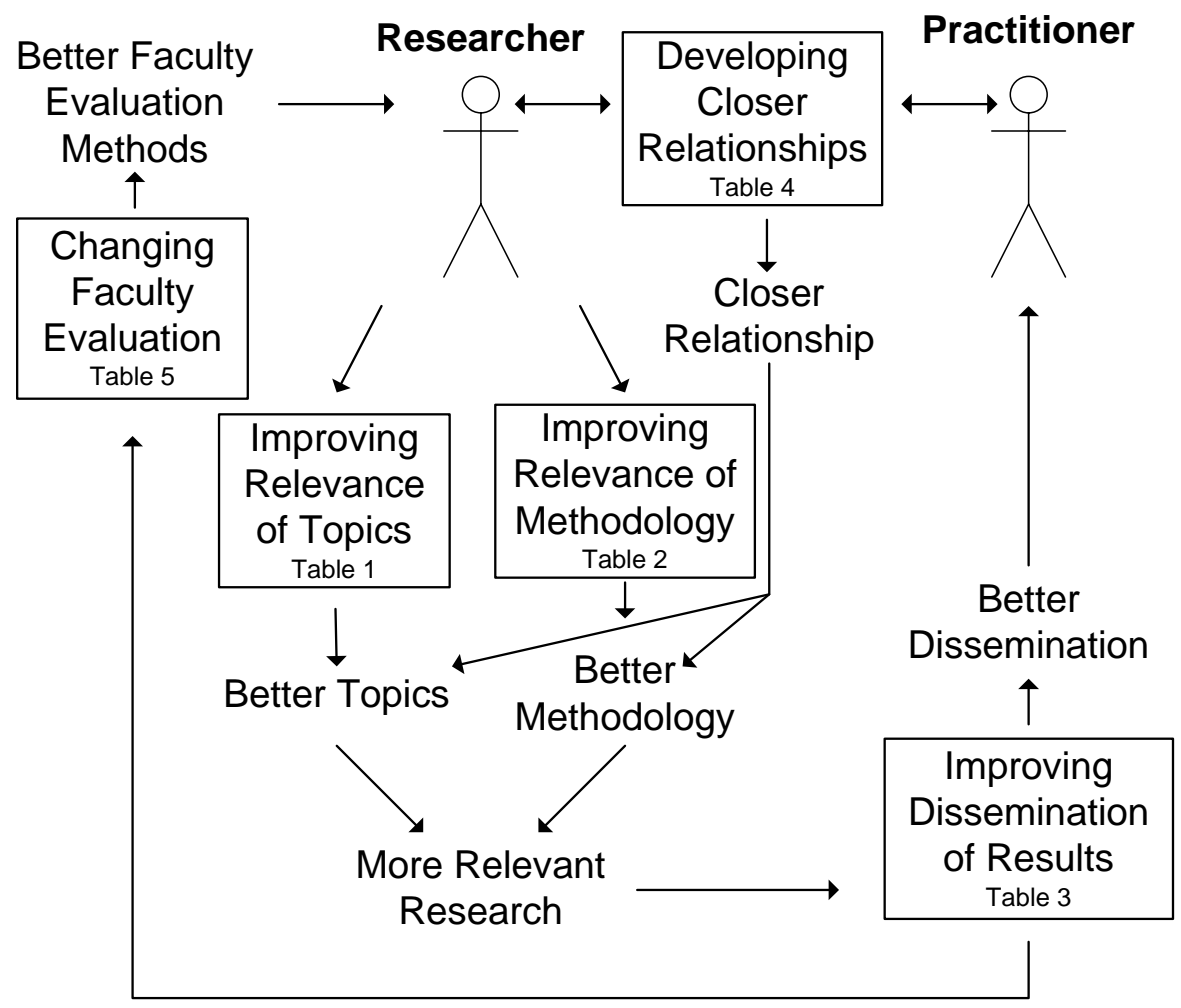

Figure 1: Actions for a relevant research agenda

Those ideas that have been suggested for improving the relevance of IS research (shown in Tables 1-5) can be viewed in both macro and micro terms. At the macro level, one can consider 
what might be done by universities and the broader IS research community as a whole. At the micro level, one can consider what an individual IS researcher might do to improve the relevance of his or her research.

Table 1. Actions for improving relevance of research topics

\begin{tabular}{|l|l|}
\hline Look to practice to identify research topics & $\begin{array}{l}\text { Benbasat \& Zmud } \\
(1999)\end{array}$ \\
\hline Insure topic is related to future interests of key stakeholders & $\begin{array}{l}\text { Benbasat \& Zmud } \\
(1999)\end{array}$ \\
\hline Focus on likely outcomes, not inputs & $\begin{array}{l}\text { Benbasat \& Zmud } \\
(1999)\end{array}$ \\
\hline Develop frames of reference useful to the practitioner & $\begin{array}{l}\text { Benbasat \& Zmud } \\
(1999)\end{array}$ \\
\hline Produce cumulative, theory-based, context-rich bodies of research & $\begin{array}{l}\text { Benbasat \& Zmud } \\
(1999)\end{array}$ \\
\hline $\begin{array}{l}\text { Consider issues contrary to commercial interests or economically unat- } \\
\text { tractive to commercial researchers }\end{array}$ & \begin{tabular}{l} 
Westfall (1999) \\
\hline Consider unsolved problems
\end{tabular} \\
\hline $\begin{array}{l}\text { Target practical research that is consumable by undergraduate and } \\
\text { graduate students }\end{array}$ & $\begin{array}{l}\text { Westfall (1999) } \\
\text { (1999) }\end{array}$ \\
\hline Include practice-driven activities in research & Lee (1999) \\
\hline Develop closer relationships with practitioners & See Table 4. \\
\hline
\end{tabular}

Table 2. Actions for improving the relevance of research methodology

\begin{tabular}{|l|l|}
\hline Adopt new research models & Robey \& Markus (1998) \\
\hline $\begin{array}{l}\text { Consider methods that produce objec- } \\
\text { tive findings rather than ones that } \\
\text { merely confirm prior assumptions and } \\
\text { beliefs }\end{array}$ & Senn (1998) \\
\hline Utilize high-tech laboratories & Watson \& Huber (2000) \\
\hline
\end{tabular}

Table 3. Actions for improving research relevance through improved dissemination of results

\begin{tabular}{|l|l|}
\hline Produce consumable research report & $\begin{array}{l}\text { Robey \& Markus } \\
(1998)\end{array}$ \\
\hline $\begin{array}{l}\text { Create a system for distribution or research results to IT professionals who } \\
\text { do not peruse the journals (Webzines, ISWorld) }\end{array}$ & Senn (1998) \\
\hline Support nontraditional research outlets & $\begin{array}{l}\text { Robey \& Markus } \\
(1998)\end{array}$ \\
\hline $\begin{array}{l}\text { Communicate outputs of research in such a way that it might be utilized by } \\
\text { practitioners }\end{array}$ & $\begin{array}{l}\text { Benbasat \& Zmud } \\
(1999)\end{array}$ \\
\hline Insure that research articles are clear, simple and concise manner & $\begin{array}{l}\text { Benbasat \& Zmud } \\
(1999)\end{array}$ \\
\hline Support journals that publish manuscripts balancing rigor and relevance & $\begin{array}{l}\text { Benbasat \& Zmud } \\
(1999)\end{array}$ \\
\hline $\begin{array}{l}\text { Support practitioners' outlets in addition to making academic journals } \\
\text { more practitioner accessible }\end{array}$ & $\begin{array}{l}\text { Davenport \& Mar- } \\
\text { kus (1999) }\end{array}$ \\
\hline
\end{tabular}




\begin{tabular}{|l|l|}
\hline Modify the traditional journal review process: & Weber (1999) \\
- Eliminate blind reviews & \\
published manuscripts & \\
$-\quad$ Maintain a public web archive of manuscripts under review \\
- Maintain a public web archive of rejected manuscripts
\end{tabular}

Table 4. Actions for developing closer relationships with practitioners

\begin{tabular}{|l|l|}
\hline Cultivate practitioner sponsorship & Robey \& Markus (1998) \\
\hline Form alliances with practitioners & Senn (1998) \\
\hline Involve practitioners in program issues & Westfall (1999) \\
\hline Keep abreast of issues most important to CIOs & Senn (1998) \\
\hline Organize student internships & Watson \& Huber (2000) \\
\hline Initiate student projects & Watson \& Huber (2000) \\
\hline Facilitate company sponsored courses & Watson \& Huber (2000) \\
\hline Offer specialized masters degrees & Watson \& Huber (2000) \\
\hline Offer training programs & Watson \& Huber (2000) \\
\hline Cooperate on secondary school programs & Watson \& Huber (2000) \\
\hline Actively use advisory boards & Watson \& Huber (2000) \\
\hline Offer symposiums with the business community & Watson \& Huber (2000) \\
\hline Initiate executive roundtables & Watson \& Huber (2000) \\
\hline Sponsor executive in residence programs & Watson \& Huber (2000) \\
\hline Support faculty internships & Watson \& Huber (2000) \\
\hline Support new business ventures & Watson \& Huber (2000) \\
\hline Initiate externally funded research centers & Watson \& Huber (2000) \\
\hline Support faculty sabbaticals and internships in corporations & $\begin{array}{l}\text { Khazanchi \& Munkvold } \\
(2001)\end{array}$ \\
\hline Encourage faculty to consult & $\begin{array}{l}\text { Khazanchi \& Munkvold } \\
(2001)\end{array}$ \\
\hline $\begin{array}{l}\text { Revise doctoral program requirements to include business ex- } \\
\text { perience }\end{array}$ & $\begin{array}{l}\text { Khazanchi \& Munkvold } \\
(2001)\end{array}$ \\
\hline
\end{tabular}




\begin{tabular}{|l|l|}
\hline $\begin{array}{l}\text { Form partnerships with professional and discipline-based or- } \\
\text { ganizations }\end{array}$ & $\begin{array}{l}\text { Khazanchi \& Munkvold } \\
(2001)\end{array}$ \\
\hline $\begin{array}{l}\text { Spend more time within industrial contexts } \\
\text { - } \quad \text { sabbatical leave or career breaks within industry }\end{array}$ & Lang (2003) \\
- associate or part-time academic posts & \\
- campus industrial parks & \\
- $\quad$ sttend practitioner conferences & \\
- developing part-time professional education programs & \\
\hline Initiate a regional knowledge network & $\begin{array}{l}\text { Soderstrom \& Nordstrom } \\
\text { (2003) }\end{array}$ \\
\hline
\end{tabular}

Table 5. Actions to encourage research relevance through the faculty evaluation process

\begin{tabular}{|l|l|}
\hline Include technical competence in faculty evaluation criteria & $\begin{array}{l}\text { Westfall } \\
\text { (1999) }\end{array}$ \\
\hline $\begin{array}{l}\text { Modify existing faculty appraisal schemes to give greater weight to professional } \\
\text { experience and competence in technical skills }\end{array}$ & Lang (2003) \\
\hline $\begin{array}{l}\text { Encourage and reward applied teaching methods that demonstrate the practical } \\
\text { utility of academic theories }\end{array}$ & Lang (2003) \\
\hline $\begin{array}{l}\text { Increase recognition for publications in peer-reviewed books and practitioner- } \\
\text { oriented outlets }\end{array}$ & Lang (2003) \\
\hline
\end{tabular}

\section{Macro Level: The Broader IS Community}

At the macro level, suggestions have been made that universities might begin recognizing publication in practitioner journals for promotion and tenure processes (Davenport \& Markus, 1999; Lang, 2003; Robey \& Markus, 1998; Westfall, 1999); however, there has been little movement in this direction. Even when practitioner publications are recognized as valuable, they are frequently given relatively little weight. For example, Louisiana State University's journal rankings for tenure and promotion includes the footnote, "Although premier professional publications can be a desirable part of one's publications portfolio because of their broad circulation and the visibility they have with the practitioner community, for promotion and tenure purposes, scholarly academic publications in the "Premier", "A" and "B" categories (especially in the researcher's major field) should make up the majority of the portfolio." (http://www.isworld.org/csaunders/lsu.htm). No practitioner outlets are listed on University of Texas at San Antonio (http://www.isworld.org/csaunders/utsa.htm). However, the University of Oklahoma has included MISQ Executive and Sloan Management Review on the target list of outlets (http://www.isworld.org/csaunders/ou.htm) and Mississippi State University includes both Harvard Business Review and Sloan Management Review on the A-journal list (http://www.isworld.org/csaunders/msu.htm). Although Web-based journals provide one way of reaching out to practitioners, purely Web-based journals were not included on any of these lists.

One way in which the relevance of IS research might be enhanced is by improving its currency. To the extent that the Web has facilitated the manuscript submission and review process, some improvement in relevance has likely been realized. However, there is no data to indicate that such improvement has been significant.

\section{Micro Level: The Individual IS Researcher}

While there is little hope of major movement toward relevance at the macro level, the picture is much more positive at the micro level. As the prior discussion has shown, individual researchers 
have realistic options for increasing the relevance of their work by developing the practitioner relationship, viewing research topics, methods and results from the practitioner perspective, and considering multiple outlets, both academic and practitioner, for publication.

There are a variety of steps that the typical IS researcher can take to initiate meaningful relationships with practitioners. (1) A researcher can attend practitioner conferences in the researcher's area of interest (Benbasat \& Zmud, 1999; Lang, 2003). For example, if the researcher's focus area is project management, they might attend a Project Management Institute Global Congress or a Cutter Consortium Summit. (2) A researcher might organize a roundtable discussion with local industry technology leaders to identify and isolate key research areas (Benbasat \& Zmud, 1999; Watson \& Huber, 2000). A successful format might include partnering with the school or college's alumni association, or appropriate student organizations. (3) A researcher might include "live" projects in his or her coursework that relate directly to his or her research interests (Watson \& Huber, 2000). Many universities have external or corporate outreach programs that can assist the researcher in finding an appropriate project and organization. (4) A researcher might facilitate company-sponsored courses. A faculty member at the University of Georgia organizes a course for a coalition of companies to teach legacy programming (Watson \& Huber, 2000). (5) An IS researcher can adopt action research methodologies such as Soft Systems Methodology (Checkland, 1999). According to Baskerville (1999), “... the adoption of action research methodologies produces highly relevant research results because it is grounded in practical action, aimed at solving an immediate problem situation while carefully informing theory." Action research is guided by common goals of both researcher and organization where gained knowledge can be immediately applied to the social-organizational problem.

Once a researcher has established a relationship with external practitioners, then the work of building a long term, and hopefully more personal, relationship begins (Benbasat \& Zmud, 1999). To facilitate a more in-depth relationship, a researcher might consider using sabbaticals, internships within corporations, and consulting (Khazanchi \& Munkvold, 2001; Lang, 2003; Watson \& Huber, 2000). Although funds are limited and such grants are highly competitive, the researcher also might consider applying for funding through either a professional organization or a major corporation (Robey \& Markus, 1999). The Society for Information Management's Advanced Practices Council supports applied research in areas that have practical application to the successful management and use of information technology to achieve business objectives (http://www.simnet.org/Content/NavigationMenu/Advanced_Practices_Council/Overview10/Ove rview.htm). Microsoft's External Research and Programs provides grants for pervasive computing, digital inclusion, technical solutions and computational sciences (http://www.microsoft.com/education/university relations.mspx).

Increased relationships with the active business IT community will not completely resolve the problem of insuring relevant IS research. For research to become more relevant, informing must be a two-way street. Just as practitioners must learn from researchers, researchers must also be willing to seek practitioner perspectives on research topics and methods. One way to do this is to regularly read what the business community reads about IT (Senn, 1998; Davenport \& Markus, 1999). Regularly scanning sites such as http://www.CIO.com, http://www.informationweek.com, and http://www.computerworld.com can provide current and sustainable topics of interest. Another way for the researcher to focus on relevant business issues involves forming a universitybased center or institute, perhaps seeking corporate sponsorship (Robey \& Markus, 1998; Senn, 1999). Institutes such as FedEx Institute of Technology at the University of Memphis (http://fedex.memphis.edu/), Commercial Human Computer Interface Research Laboratories at the University of Maryland (http://www.otal.umd.edu/guse/university.html\#sect4), Vanderbilt University’s Sloan Center for Internet Retailing (http://elab.vanderbilt.edu/) help to bring researchers closer to business interests at the same time as they help disseminate research to the 
practitioner community. Since practitioners do not actively follow research journals (Benbasat \& Zmud, 1999), one way to better inform practitioners of results without forgoing the prestige of academic journals is to submit each research result separately for two audiences: academic and practitioner, with a style appropriate for each distinct reader (Benbasat \& Zmud, 1999; Robey \& Markus, 1998; Westfall, 1999). When presenting research to practitioners, models must be practical; findings must be implementable and pragmatic (Benbasat \& Zmud, 1999; Senn, 1998).

Figure 2 details specific actions that individual researchers can take to make their research more relevant. Some of these actions will increase the researchers' knowledge and appreciation of practitioner problems. Such actions involve a flow of information primarily from practitioners to researchers. Other actions involve an opposite information flow, from researchers to practitioners, as researchers make their research more available and more user-friendly for practitioners. Ultimately, if IS research is to be relevant as a whole, then individual researchers must take the initiative in first establishing relationships with practitioners and then building upon those relationships to become ever closer to the practitioner community.

Flow of Information

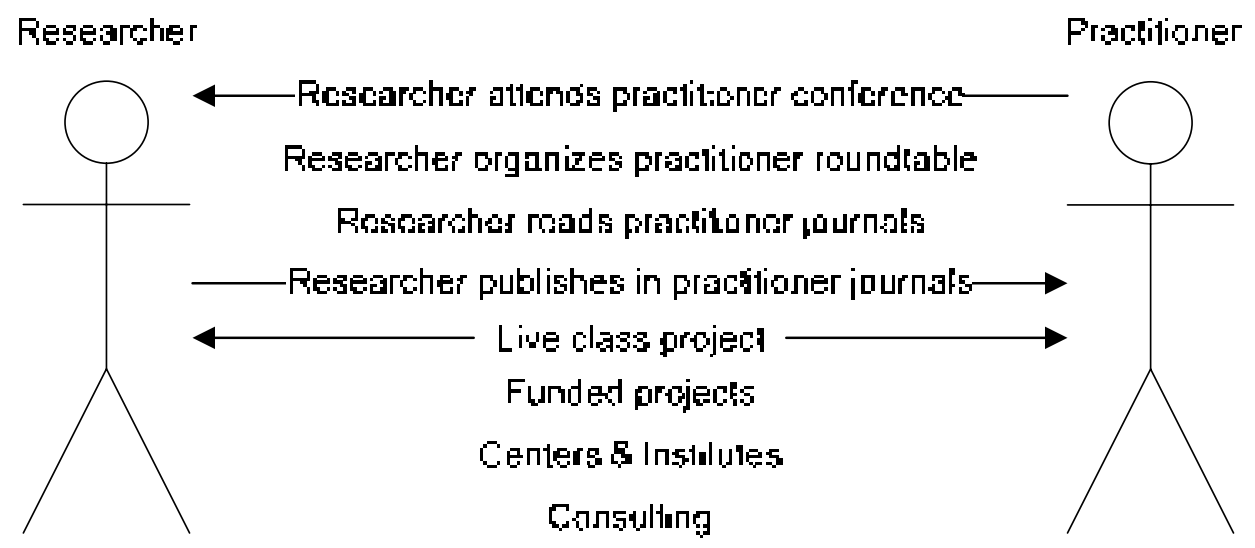

Figure 2: Flow of Information

\section{Conclusion}

Though the issue of IS research relevance has faded from top-tier journals, the problem has not been resolved. This article provides the first comprehensive digest of major papers relating to IS research rigor and relevance. It also recognizes that the problem of relevance is not one that is likely to be solved at the global level, no matter how distinguished the discussants or how glorious the plans. Rather, the relevance of IS research ultimately will be determined by each individual researcher. To facilitate individual researchers' progress in moving toward ever greater relevance, this research provides a concise plan of specific actions that are within the control of each individual IS researcher. In the end, the relevance of each research piece will be determined largely by the extent of its researchers' willingness to seek out practitioner viewpoints, formulate research problems that are meaningful to practitioners and implementable, and promote their own research in formats and terms that the IS practitioner community can recognize and appreciate. Our fate, it seems, is in our own hands. 


\section{References}

Baskerville, R. L. (1999, October). Investigating information systems with action research. Communications of the Association for Information Systems, 2 (19). Retrieved February 28, 2006 from http://cais.aisnet.org/contents.asp?show=2

Benbasat, I. \& Zmud, R.W. (1999, March). Empirical research in information systems: The practice of relevance. MIS Quarterly, 23 (1), 3-16.

Bhattacherjee, A. (2001, March). Understanding and evaluating relevance in IS research. Communications of the Association for Information Systems, 6 (6). Retrieved October 13, 2005 from http://cais.aisnet.org/contents.asp?show $=6$

Checkland, P. (1999, July). Soft Systems Methodology: A 30-year retrospective. Plenary Address at the $17^{\text {th }}$ International Conference of the System Dynamics Society and the $5^{\text {th }}$ Australian \& New Zealand Systems Conference, Wellington, New Zealand. Retrieved February 26, 2006 from http://www.systemdynamics.org/conf1999/PAPERS/KEYNOTE3.PDF

Davenport, T.H \& Markus, M.L. (1999, March). Rigor vs. relevance revisited: Response to Benbasat and Zmud. MIS Quarterly, 23 (1), 19-23.

Dennis, A. R. (2001, March). Relevance in information systems research. Communications of the Association for Information Systems, 6 (10). Retrieved October 13, 2005 from http://cais.aisnet.org/contents.asp?show $=6$

Fitzgerald, B. (2003). Informing each other: Bridging the gap between researcher and practitioners. Informing Science Special Series: Informing Each Other, 6. Retrieved November 29, 2005 from http://inform.nu/Articles/Vol6/IndexV6.htm

Glass, R. L. (2001, March). Rigor vs. relevance: A practitioner's eye view of an explosion of IS opinions. Communications of the Association for Information Systems, 6 (2). Retrieved October 13, 2005 from http://cais.aisnet.org/contents.asp?show $=6$

Gray, P. (2001, March). Introduction to the special volume on relevance. Communications of the Association for Information Systems, 6 (1). Retrieved October 13, 2005 from http://cais.aisnet.org/contents.asp?show $=6$

Ho, J. K. (2000, April-June). Bridging academic research and business practice with the new media. Information Resources Management Journal, 13 (2), 6-14.

Information systems as a field of academic study. (2003, Winter). Database for Advances in Information Systems, 34 (1), 9.

Khazanchi, D. \& Munkvold, B. E. (2001, March). Expanding the notion of relevance in IS research: A proposal and some recommendations. Communications of the Association for Information Systems, 6 (14). Retrieved October 13, 2005 from http://cais.aisnet.org/contents.asp?show=6

Lang, M. (2003). Communicating academic research findings to IS professionals: An analysis of problems. Informing Science Special Series: Informing Each Other, 6. Retrieved November 29, 2005 from http://inform.nu/Articles/Vol6/IndexV6.htm

Lee, A. S. (1999, March). Rigor and relevance in MIS research: Beyond the approach of positivism alone. MIS Quarterly, 23 (1), 29-34.

Moody, D. L. (2003). Using the world wide web to connect research and professional practice: Towards evidence-based practice. Informing Science Special Series: Informing Each Other, 6. Retrieved November 29, 2005 from http://inform.nu/Articles/Vol6/IndexV6.htm

Robey, D. \& Markus, M. L. (1998, Winter). Beyond rigor and relevance: Producing consumable research about information systems. Information Resources Management Journal, 11 (1), 7-15.

Senn, J. (1998, Winter). The challenge of relating IS research to practice. Information Resources Management Journal, 11 (1), 23-28. 
Söderström, M. \& Nordström, T. (2003). Regional IS knowledge networks: Elaborating the theme of relevance of IS research. Informing Science Special Series: Informing Each Other, 6. Retrieved November 29, 2005 from http://inform.nu/Articles/Vol6/IndexV6.htm

Watson, H. J. \& Huber, M. (2000, May). Innovative ways to connect information systems programs to the business community. Communications of the Association for Information Systems, 3 (11). Retrieved October 13, 2005 from http://cais.aisnet.org/contents.asp?show=3

Watson, H. J., Taylor, K. P., Higgins, G., Kadlec, C. \& Meeks, M. (1999, July). Leaders assess the current state of the IS academic discipline. Communications of the Association for Information Systems, 2 (2). Retrieved October 13, 2005 from http://cais.aisnet.org/contents.asp?show=2

Weber, R. (1999, August). The journal review process: A manifesto for change. Communications of the Association for Information Systems, 2 (12). Retrieved October 13, 2005 from http://cais.aisnet.org/contents.asp?show $=2$

Westfall, R. D. (1999, September). An IS research relevance manifesto. Communications of the Association for Information Systems, 2 (14). Retrieved October 13, 2005 from http://cais.aisnet.org/contents.asp?show=2

\section{Biographies}

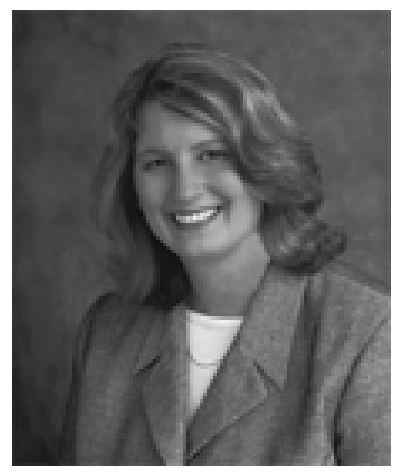

Theresa Steinbach began the Ph.D. program at DePaul CTI in January 2000, having received her M.S. in Information Systems in June 1999. She also holds an M.B.A. in Quantitative Economics and a B.A. in Mathematics from DePaul University. Prior to teaching full-time for DePaul CTI, Terry owned her own consulting firm that specialized in maximizing technology for business growth and profits. Her client base included representatives from the banking and nursing home industries, accounting firms, mortgage bankers, park districts and other municipal entities, as well as small and mid-size retail businesses.

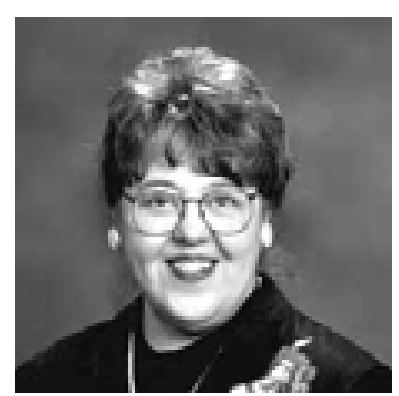

Linda V. Knight is Associate Dean of DePaul University's School of Computer Science, Telecommunications, and Information Systems. She is also Director of DePaul CTI's Center for the Strategic Application of Emerging Technologies (SAET), a CTI research group that explores leveraging new and emerging technology within organizations. She teaches and conducts research in the area of Information Technology strategy, development, and implementation. An Associate Editor of the Information Resources Management Journal, she also is Editorin-Chief of the Journal of IT Education, as well as Past President and Fellow of the Society for the Advancement of Information Systems, an affiliate of MBAA International. She is a member of the Editorial Advisory Board of the Journal of Cases on Information Technology (JCIT), and is also a member of the Information Resources Management Association Executive Council. She serves on MBAA International's Executive Board. An entrepreneur and IT consultant, she has held industry positions in IT management and quality assurance management. In addition to a Ph.D. in computer science from DePaul CTI, she holds a B.A. in mathematics and an MBA, both from Dominican University. 